\title{
Radiological assessment of peri-implant bone loss: a 12-month retrospective study.
}

\author{
AJ. Flichy-Fernández ${ }^{1}$, J. Ata-Ali ${ }^{2}$, C. Palma-Carrió ${ }^{3}$, D. Peñarrocha-Oltra ${ }^{3}$, J. Conejero ${ }^{3}$, M. Peñarrocha ${ }^{4}$ \\ ${ }^{1}$ Collaborating Professor of Oral Surgery. Master in Oral Surgery and Implantology. Valencia University Medical and Dental \\ School. \\ ${ }^{2}$ DDS. Primary Public Health Service Dentist. Valencian Health Service. Master in Oral Surgery and Medicine. Master in Oral \\ Surgery and Implantology. Valencia University Medical and Dental School. \\ ${ }^{3}$ DDS. Resident of the Master in Oral Surgery and Implantology. Valencia University Medical and Dental School. \\ ${ }^{4}$ Associate Professor of Oral Surgery. Valencia University Medical and Dental School. Valencia (Spain).
}

\author{
Correspondence: \\ Cirugía Bucal \\ Clínicas Odontológicas \\ Gascó Oliag 1 \\ 46021 - Valencia (Spain) \\ Maria.Penarrocha@uv.es
}

Flichy-Fernández AJ, Ata-Ali J, Palma-Carrió C, Peñarrocha-Oltra D, Conejero J, Peñarrocha M. Radiological assessment of peri-implant bone loss: a 12-month retrospective study. J Clin Exp Dent. 2011;3(5):e430-4. http://www.medicinaoral.com/odo/volumenes/v3i5/jcedv3i5p430.pdf

\begin{abstract}
Introduction: Following dental implant loading, marginal bone loss after one year must be evaluated to check correct maintenance of the bone levels.

Objectives: To assess implant treatment success and quantify marginal bone loss 6 and 12 months after loading. Material and method: Sixty-one MIS ${ }^{\circledR}$ implants with a $1.8 \mathrm{~mm}$ machined neck were placed in 26 patients. Implant success was based on the criteria of Buser. Radiological controls were made 6 and 12 months after loading, measuring bone loss mesial and distal.

Results: Twenty-two patients with 56 implants were included: 32 in the maxilla and 24 in the mandible. Two implants failed in two patients during the osseointegration phase (both in the maxilla), yielding an implant success rate of $96.4 \%$. After 6 months, bone loss was $0.80 \pm 1.04 \mathrm{~mm}$ mesial and $0.73 \pm 1.08 \mathrm{~mm}$ distal, while after 12 months bone loss was $0.92 \pm 1.02$ mesial and $0.87 \pm 1.01$ distal.

Conclusions: Bone loss 6 and 12 months after machined neck implant placement was within the normal ranges described in the literature.
\end{abstract}

Key Words: Peri-implant bone loss, marginal bone loss, dental implants, machined neck. 


\section{Introduction}

Bone loss occurs after the placement of dental implants, extending to the first thread of the implant body or to first contact of the bone with the rough surface $(1,2)$.

Marginal bone loss is evaluated radiographically, and is usually no greater than $1.5 \mathrm{~mm}$ in the first year $(3,4)$. According to Piao et al. (5), bone loss after one year was $0.89 \pm 0.27 \mathrm{~mm}$ with machined neck implants such as the MIS $^{\circledR}$ dental implants.

The timing of radiographic evaluation is important. In some studies the first X-ray is obtained on placing the prosthesis, while in other studies it is obtained on placing the implant $(6,7)$. Longitudinal studies (7-12) with initial X-rays obtained at implant placement reveal significant bone loss before insertion of the definitive restoration. Such bone loss may depend upon the location of the upper part of the implant in relation to the alveolar crest, the creation of an interface (microgap) between the implant components, and the type of neck and platform of the implant.

Given the importance of evaluating implant bone loss in the first year after placement, the present study was designed to examine the implant success rate and marginal bone loss 6 and 12 months after prosthetic loading.

\section{Material and Method}

A retrospective clinical study was made in the Oral Surgery Unit of a University Hospital between January 2008 and June 2009. The patient inclusion criteria were: 1) patients with single missing teeth programmed for restoration with dental implants; 2) partially edentulous patients with free extremities programmed for restoration with dental implants; 3) patients requiring dental implant restoration of the entire dental arch; and 4) patients with sufficient bone width (minimum $6.75 \mathrm{~mm}$ ) and height (minimum $8.5 \mathrm{~mm}$ ). The exclusion criteria were: 1) patients with systemic diseases contraindicating any type of surgery; 2) patients receiving or who have received bisphosphonates; 3 ) patients with active disease of the implant bed (e.g., residual cysts); and 4) patients with bone atrophy requiring bone regeneration in both width and height.

All the patients included in the study received MIS $^{\circledR}$ dental implants (MIS Implants Technologies, Shlomi, Israel), with a $1.8 \mathrm{~mm}$ machined neck (Mistral ${ }^{\mathbb{}}$ ). Two patients failing to report for the control visits were excluded.

\section{Surgical technique}

The MIS ${ }^{\circledR}$ dental implants were placed using the same surgical protocol in all cases. Anesthesia was provided in the form of $4 \%$ articaine with epinephrine $1: 100,000$. A crestal incision was made with the raising of a fullthickness mucoperiosteal flap. The surgical zone was subjected to curettage before the drilling phase, according to the recommendations of the manufacturer. The drill speed was reduced from 1200 to $800 \mathrm{rpm}$ as the drill diameter was increased, in order to reduce heating of the bone at the implant site. Drilling was carried out under irrigation with cold saline solution, and the implant was placed with a counter-angle and applying 35 $\mathrm{N}$ of torque. Suturing was carried out with $3 / 0$ silk. All surgeries were completed in a single step.

Periapical X-ray controls of all the implants were made after the operation, recording the initial or baseline bone level with respect to the platform of the implant.

Postoperative control

A three-month osseointegration period was observed in both the maxilla and the mandible. During this period, controls were made one week and one month after implant placement to assess the clinical evolution of the surgical zone. Following the osseointegration period, the prosthetic restorations were positioned over the dental implants.

Success criteria and data analyzed

Implant success was based on the clinical and radiographic criteria of Buser (13): 1) absence of clinical mobility of the implant; 2) absence of pain or subjective sensation; 3) absence of recurrent peri-implant infection; and 4) absence of continuous radiotransparencies around the implant 3,6, and 12 months after loading.

The following patient data were collected: smoking $(<10$ cigarettes/day, 10-20 cigarettes/day, $>20$ cigarettes/day), gender and age. In relation to the implants, we documented their location, diameter and the length.

Radiographic assessment

Intraoral X-rays were used to measure marginal bone loss. The radiographic exploration was carried out with the intraoral XMind system (Groupe Satelec-Pierre Rolland, Bordeaux, France) and the RVG intraoral digital sensor (Kodak Dental System, Atlanta, GA, USA). In order to reproduce the X-ray angles in posterior reviews, XCP positioners were used (Dentsply, Des Plaines, IL), placing the guide bar parallel to the direction of the Xray beam, perpendicular to the digital sensor.

Use was made of the Digora ${ }^{\circledR}$ system software (Digo$\mathrm{ra}^{\circledR}$, Soredex, Sweden) for measuring marginal bone loss based on the radiographic criteria of Buser (13). Two reference points were marked on the surface of the implant platform and joined with a line representing height zero. We then traced two vertical lines perpendicular to the zero line to first contact with the bone, mesial and distal. The differences between the values of the first measurement (after implant placement) and those of the second (6 months after loading) and third measurement (12 months after loading) were used to establish marginal bone loss (Figures 1 and 2).

Statistical analysis

The data were processed using the SPSS version 17.0 statistical package (SPSS Inc., Chicago, IL, USA) for Microsoft Windows. The Student t-test was used for the 


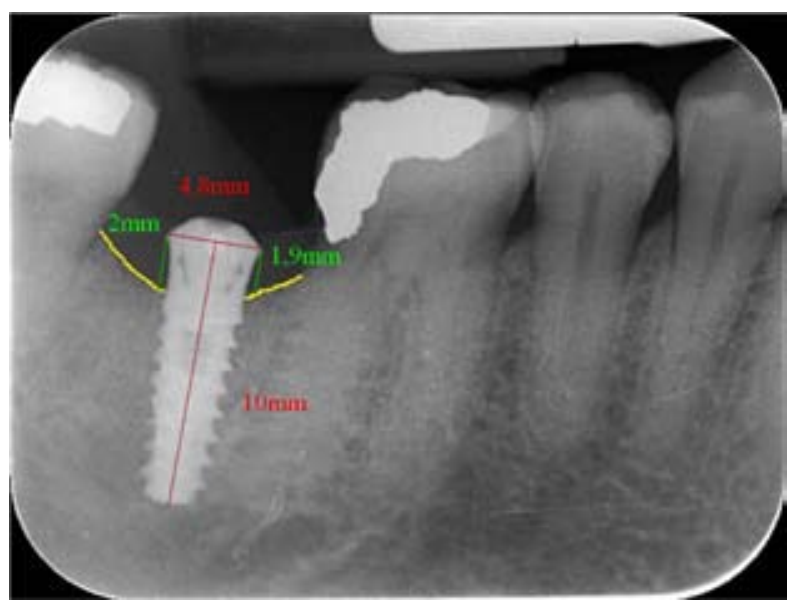

Fig. 1. Radiographic measurements at the time of dental implant placement.

comparative analysis.

\section{Results}

A total of 26 patients were operated upon, and two subjects who failed to report for the control visits were excluded from the study. Two implants failed in two patients, both placed in the maxilla. We included 22 patients (12 males and 10 females), with a mean age of $55.8 \pm 11.1$ years. Most of the patients $(68 \%)$ were nonsmokers, while $18 \%$ smoked less than 10 cigarettes a day, 9\% smoked 10-20 cigarettes day, and 4\% smoked more than 20 cigarettes a day. A total of 56 implants were placed: 32 in the maxilla and 24 in the mandible. Regarding implant diameter, $21 \%$ of the implants measured $3.75 \mathrm{~mm}$ in diameter, $55 \%$ measured $4.1 \mathrm{~mm}$, and $23 \%$ measured $4.8 \mathrm{~mm}$ in diameter. In turn, $7 \%$ of the implants measured $8 \mathrm{~mm}$ in length, $32 \%$ measured 10 $\mathrm{mm}, 34 \%$ measured $11.5 \mathrm{~mm}$, and $26 \%$ measured 13 $\mathrm{mm}$ in length. The success rate was $96.4 \%$.

Bone loss after 6 months was $0.81 \pm 0.31 \mathrm{~mm}$ mesial and $0.67 \pm 0.37 \mathrm{~mm}$ distal; after 12 months the loss was $0.89 \pm 0.29 \mathrm{~mm}$ mesial and $0.78 \pm 0.40 \mathrm{~mm}$ distal. The global bone loss was therefore $0.74 \pm 0.20 \mathrm{~mm}$ after 6 months and $0.83 \pm 0.22 \mathrm{~mm}$ after 12 months - this loss being statistically nonsignificant $(\mathrm{p}>0.05)$ (Figure 3 ).

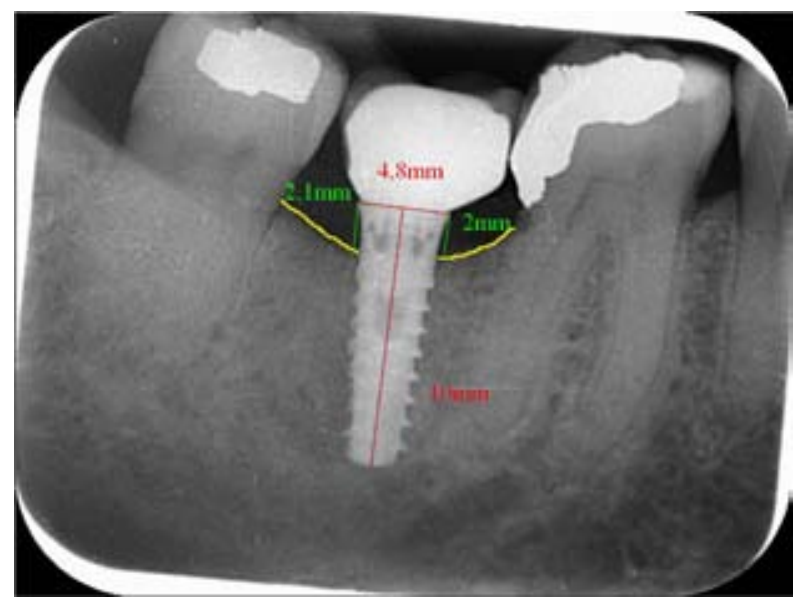

Fig. 2. Radiographic measurements 12 months after prosthetic loading of the dental implant in Figure 1.

No statistically significant differences $(p>0.05)$ were observed on relating smoking habit to bone loss - the latter being $0.79 \pm 0.24 \mathrm{~mm}$ after 6 months among the smokers and $0.85 \pm 0.44 \mathrm{~mm}$ among the non-smokers. In turn, bone loss was $0.86 \pm 0.21 \mathrm{~mm}$ after 12 months among the smokers and $0.94 \pm 0.42 \mathrm{~mm}$ among the nonsmokers (Table 1).

Patient age and gender did not appear to influence bone loss - the values obtained failing to reach statistical significance ( $\mathrm{p}>0.05)$, as can be seen in Table 1 .

The two failed implants were both located in the maxi1la, and bone loss was slightly greater in the maxilla than in the mandible - though these data again failed to reach statistical significance ( $\mathrm{p}>0.05)$.

The variables implant diameter and length likewise did not condition increased bone loss, and no significant differences were observed $(\mathrm{p}>0.05)$ (Table 2$)$.

\section{Discussion}

The results obtained in our study in relation to bone loss are very similar to those reported in other studies $(5,14$, 15) involving a similar number of patients, marginal bone loss measured after one year, and a similar implant design. Piao et al. (5) evaluated 45 machined neck implants and recorded a global bone loss of $0.81 \mathrm{~mm}$ after

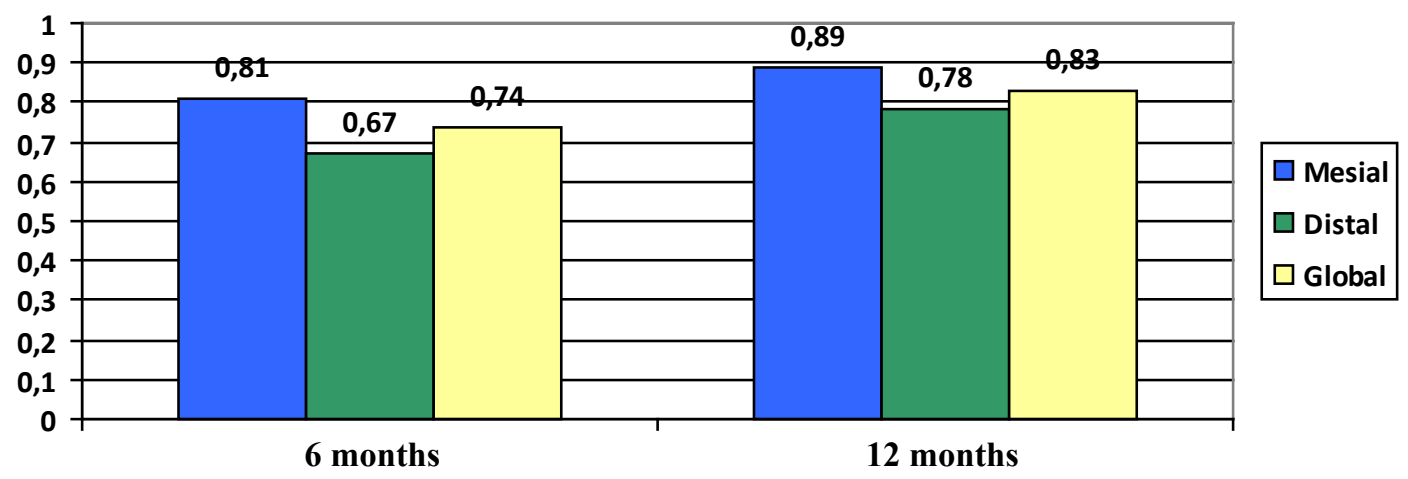

Fig. 3. Mesial, distal and global marginal bone loss after 6 and 12 months. 


\begin{tabular}{|l|l|l|l|l|l|}
\hline \multicolumn{2}{|l|}{ VARIABLES } & No. PATIENTS & $\begin{array}{l}\text { BONE LOSS AT } \\
6 \text { MONTHS }\end{array}$ & $\begin{array}{l}\text { BONE LOSS AT } \\
12 \text { MONTHS }\end{array}$ & P-VALUE \\
\hline \multirow{2}{*}{ Gender } & Male & 12 & $0.77 \pm 0.23 \mathrm{~mm}$ & $0.88 \pm 0.25 \mathrm{~mm}$ & $>0.05$ \\
\cline { 2 - 6 } & Female & 10 & $0.71 \pm 0.15 \mathrm{~mm}$ & $0.78 \pm 0.17 \mathrm{~mm}$ & $>0.05$ \\
\hline \multirow{2}{*}{ Age } & $<60$ years & 10 & $0.77 \pm 0.22 \mathrm{~mm}$ & $0.88 \pm 0.23 \mathrm{~mm}$ & $>0.05$ \\
\cline { 2 - 6 } & $>60$ years & 10 & $0.70 \pm 0.17 \mathrm{~mm}$ & $0.78 \pm 0.19 \mathrm{~mm}$ & $>0.05$ \\
\hline \multirow{2}{*}{ Smoking } & Smoker & 7 & $0.70 \pm 0.17 \mathrm{~mm}$ & $0.78 \pm 0.20 \mathrm{~mm}$ & $>0.05$ \\
\cline { 2 - 6 } & Non-smoker & 15 & $0.82 \pm 0.24 \mathrm{~mm}$ & $0.94 \pm 0.24 \mathrm{~mm}$ & $>0.05$ \\
\hline
\end{tabular}

Table 1. Relationship between the different patient characteristics and bone loss after 6 and 12 months.

\begin{tabular}{|l|l|l|l|l|l|}
\hline \multicolumn{2}{|l|}{ VARIABLES } & No. IMPLANTS & $\begin{array}{l}\text { BONE LOSS AT } \\
\text { 6 MONTHS }\end{array}$ & $\begin{array}{l}\text { BONE LOSS AT } \\
\text { 12 MONTHS }\end{array}$ & P-VALUE \\
\hline \multirow{2}{*}{ Location } & Maxilla & 32 & $0.90 \pm 0.25 \mathrm{~mm}$ & $0.98 \pm 0.26 \mathrm{~mm}$ & $>0.05$ \\
\cline { 2 - 6 } & Mandible & 24 & $0.65 \pm 0.21 \mathrm{~mm}$ & $0.75 \pm 0.20 \mathrm{~mm}$ & $>0.05$ \\
\hline \multirow{3}{*}{ Implant diameter } & $\leq 4.1 \mathrm{~mm}$ & 43 & $0.67 \pm 0.20 \mathrm{~mm}$ & $0.76 \pm 0.24 \mathrm{~mm}$ & $>0.05$ \\
\cline { 2 - 6 } & $\geq 4.8 \mathrm{~mm}$ & 13 & $0.77 \pm 0.20 \mathrm{~mm}$ & $0.86 \pm 0.21 \mathrm{~mm}$ & $>0.05$ \\
\hline \multirow{2}{*}{ Implant length } & $\leq 10 \mathrm{~mm}$ & 22 & $0.79 \pm 0.25 \mathrm{~mm}$ & $0.85 \pm 0.27 \mathrm{~mm}$ & $>0.05$ \\
\cline { 2 - 6 } & $\geq 12 \mathrm{~mm}$ & 34 & $0.70 \pm 0.15 \mathrm{~mm}$ & $0.81 \pm 0.18 \mathrm{~mm}$ & $>0.05$ \\
\hline
\end{tabular}

Table 2. Relationship between the implant number and characteristics and bone loss after 6 and 12 months.

one year. Nickenig et al. (16), in a study of 63 implants, recorded a loss of $0.8 \mathrm{~mm} \pm 2.4 \mathrm{~mm}$ after 6 months, versus $1.1 \mathrm{~mm} \pm 3 \mathrm{~mm}$ after 12 months. Bratu et al. (17), in 48 implants, recorded a marginal bone loss of $0.56 \pm 0.23$ $\mathrm{mm}$ after 6 months and $0.69 \pm 0.25 \mathrm{~mm}$ after 12 months of follow-up - these values being similar to those of our own study.

According to Cochran et al. (18), peri-implant bone remodeling after implant placement is more accentuated in the first 6 months after surgery. These authors found $86 \%$ of the bone loss to take place in the first 6 months between the initial implant insertion control and the control at final placement of the prosthesis. They recorded a mean bone loss of $2.44 \pm 1.20 \mathrm{~mm}$ after 6 months. The bone loss slowly increased until stable levels were reached in 596 implants assessed after 5 years. All the implants were placed in a single step and exposed in the mouth in the same way as in our study, where the bone loss involving MIS ${ }^{\circledR}$ implants was seen to be comparatively smaller: $0.80 \pm 1.04 \mathrm{~mm}$ mesial and $0.73 \pm 1.08 \mathrm{~mm}$ distal. Other investigators such as Lee et al. (2), with 70 patients subjected to three years of follow-up, and Hartman et al. (7), with 42 patients and 5 years of follow-up, likewise consider most bone loss to occur in the first 6 months, followed by gradual stabilization as evidenced by the posterior annual controls. Our own data coincide with these observations (Table 1)

We observed no relationship between bone loss and smoking, in contrast to other studies (19) in which bone loss was found to be increased among smokers. Lindquist et al. (20), in 45 patients subjected to 10 years of followup, and Bain and Moy (21), in 540 patients subjected to 6 years of follow-up, found bone loss to be more than twice as great among smokers. However, Minsk et al. (22) observed no significant differences between smokers and non-smokers in a study of 1263 implants subjected to 6 years of follow-up, in coincidence with our own observations. These results must be viewed with caution, however, and studies involving larger samples are needed in order to draw reliable conclusions.

In most studies (14, 23-26), and in coincidence with our own observations, patient age and gender do not appear to influence peri-implant bone loss.

Regarding the location of the implants, Kempainen et al. (27), Peñarrocha et al. (19), and Danza et al. (28) found marginal bone loss during the first year to be greater in implants located in the maxilla than in implants placed in the mandible. This increased maxillary bone loss could be due to possible differences in bone remodeling capacity between the mandibular and maxillary bone - the latter being more vascularized and with a greater remodeling potential during the healing phase after implant placement (27). These data coincide with our own observations of greater marginal bone loss in maxillary implants - though the results were not statistically significant. Peri-implant bone loss has been related to the diameter and length of the implant. In 1997, Ivanoff et al. (29) suggested that a greater diameter could lessen bone loss. Grunder et al. (15) reported greater bone loss with short and narrow implants. Other authors in turn have observed no relationship between the dimensions of the implant and peri-implant bone loss (30), in coincidence with our own study, where neither implant diameter nor implant length were correlated to bone loss. 


\section{Conclusions}

The implant success rate and the bone loss values recorded 6 and 12 months after loading coincide with the normal values described in the literature, in the context of studies with implants of similar characteristics. However, studies with a larger number of implants and involving longer periods of follow-up are needed in order to draw firm conclusions.

\section{References}

1. Astrand P, Engquist B, Dahlgren S, Gröndahl K, Engquist E, Feldmann H. Astra Tech and Brånemark system implants: a 5-year prospective study of marginal bone reactions. Clin Oral Implants Res. 2004;15:413-20.

2. Lee DW, Choi YS, Park KH, Kim CS, Moon IS. Effect of microthread on the maintenance of marginal bone level: a 3-year prospective study. Clin Oral Implants Res. 2007;18:465-70.

3. Becker W, Becker BE, Israelson H, Lucchini JP, Handelsman M, Ammons W, y cols. One-step surgical placement of Brånemark implants: a prospective multicenter clinical study. Int J Oral Maxillofac Implants. 1997; 12:454-62.

4. Weber HP, Buser D, Fiorellini JP, Williams RC. Radiographic evaluation of crestal bone levels adjacent to nonsubmerged titanium implants. Clin Oral Implants Res. 1992;3:181-8.

5. Piao CM, Lee JE, Koak JY, Kim SK, Rhyu IC, Han CH, et al. Marginal bone loss around three different implant systems: radiographic evaluation after 1 year. J Oral Rehabil. 2009;36:748-54.

6. Albrektsson T, Zarb G, Worthington P, Eriksson AR. The long-term efficacy of currently used dental implants: A review and proposed criteria of success. Int J Oral Maxillofac Implants 1986;1:11-25.

7. Hartman GA, Cochran DL. Initial implant position determines the magnitude of crestal bone remodeling. J Periodontol 2004;75:57277.

8. Hermann JS, Cochran DL, Nummikoski PV, Buser D. Crestal bone changes around titanium implants. A radiographic evaluation of unloaded nonsubmerged and submerged implants in the canine mandible. J Periodontol 1997;68:1117-30.

9. Hermann JS, Buser D, Schenk RK, Cochran DL. Crestal bone changes around titanium implants. A histometric evaluation of unloaded non-submerged and submerged implants in the canine mandible. J Periodontol 2000;71:1412-24.

10. Cochran D. Implant therapy I. Ann Periodontol 1996;1:707-91.

11. Karoussis IK, Brägger U, Salvi GE, Bürgin W, Lang NP. Effect of implant design on survival and success rates of titanium oral implants: A 10-year prospective cohort study of the ITI Dental Implant System. Clin Oral Implants Res 2004;15:8-17.

12. Brägger U, Gerber C, Joss A, Haenni S, Meier A, Hashorva E, et al. Patterns of tissue remodeling after placement of ITI Dental Implants using an osteotome technique: A longitudinal radiographic case cohort study. Clin Oral Implants Res 2004;15:158-66.

13. Buser D, Mericske-Stern R, Dula K, Lang NP. Clinical experience with one-stage, non-submerged dental implants. Adv Dent Res 1999;13:153.

14. Bryant SR, Zarb G. Osseointegration of oral implants in older and younger adults. Int J Oral Maxillofac Implants 1998;13:492-499.

15. Grunder U, Polizzi G, Goené R, et al. A 3-year prospective multicenter follow-up report on the immediate and delayed-immediate placement of implants. Int J Oral Maxillofac Implants 1999;14:210216.

16. Nickening HJ, Wichmann M, Schlegel KA, Nkenke E, Eitner S. Radiographic evaluation of marginal bone levels adjacent to parallel-screw cylinder machined-neck implants and rough-surfaced microthreaded implants using digitized panoramic radiographic. Clin Oral Implants Res. 2009;20:550-4.

17. Bratu EA, Tandlich M, Shapira L. A rough surface implant neck with microthreads reduces the amount of marginal bone loss: a prospective clinical study. Clin Oral Implants Res. 2009;20:827-
32.

18. Cochran DL, Nummikoski V, Schoolfield JD, Jones AA, Oates TW. A prospective multicenter 5-year radiographic evaluation of crestal bone levels over time in 596 dental implants placed in 192 patients. J Periodontol 2009;80:725-33.

19. Peñarrocha M, Palomar M, Sanchis JM, Guarinós J, Balaguer J. Radiologic study of marginal bone loss around 108 dental implants and its relationship to smoking, implant location, and morphology. Int J Oral Maxillofac Implants 2004;19:861-867.

20. Lindquist LW, Carlsson GE, Jemt T. Association between marginal bone loss around osseointegrated mandibular implants and smoking habits: A 10-year follow-up study. J Dent Res 1997;76:166774.

21. Bain CA, Moy PK. The association between the failure of dental implants and cigarette smoking. Int J Oral Maxillofac Implants 1993;8:609-615.

22. Minsk L, Polson AM, Weisgold et al. outcome failures of endosseous implants from a clinical training center. Compend Contin Educ Dent 1996;17:848-850,852-854,856.

23. Behneke A, Behneke N, D'Hoedt B, Wagner W. hard and soft tissue reactions to ITI screw implants: 3-yar longitudinal results of a prospective study. Int J Oral Maxillofac Implants 1997;12:749757.

24. Fartash B, Eliasson S, Arvidson K. Mandibular single crystal sapphire implants: changes in crestal bone levels over three years. Clin Oral Implants Res 1995;6:181-188.

25. Andersson B, Odman O, Carlsson GE. A study of 184 consecutive patients referred for single-tooth replacement. Clin Orl Implants Res 1995;6:232-237.

26. Boronat A, Peñarrocha M, Carrillo C, Martí E. Marginal bone loss in dental implants subjected to early loading ( 6 to 8 weeks postplacement) with a retrospective short-term follow-up. J Oral Maxillofac Surg 2008; 66:246-250.

27. Kemppainen P, Eskola S, Ylipaavalniemi P. A comparative prospective clinical study of two single-tooth implants: a preliminary report of 102 implants. J Prosthet Dent 1997;77:382-7.

28. Danza M, Tortora P, Quaranta A, Perrotti V, Vozza I, Piattelli A. Randomised study for the 1-year crestal bone maintenance around modified diameter implants with different loading protocols: a radiographic evaluation. Clin Oral Investig. 2010;14:417-26.

29. Ivanoff CJ, Sennerby C, Johansson B, Rangert B, Lekholm U. Influence of implants diameters on the integration of screw implants; An experimental study in rabbits. Int J Oral Maxillofac Surg 1997;26:141-148.

30. Peñarrocha-Diago M, Carrillo-García C, Boronat-Lopez A, GarcíaMira B. Comparative study of wide-diameter implants placed after dental extraction and implants positioned in mature bone for molar replacement. Int J Oral Maxillofac Implants 2008;23:497-501. 